\title{
THIS LIBRARY WE DEDICATE
}

\author{
BY ROY F. NICHOLS
}

Roy F. Nichols, Vice-Provost of the University of Pennsylvania and Dean of the Graduate School of Arts and Sciences, Professor of History and winner of the Pulitzer Prize (1949-for The Disruption of American Democracy), has long taken an active interest in the Rutgers Library. A Rutgers man of the class of 1918 , he later received his Ph.D. from Columbia, and has won several honorary degrees for his scholarship in American History. Since 1950 he has been a member of the Rutgers Board of Trustees, and as chairman of the Trustees' Committee on the Library was active in the planning of the new Library. He is also a member of the Rutgers University Press Council and the Advisory Board of the Research Council.

S WE DEDICATE this great Rutgers Library we are bound to look in two directions. To understand it we must look 1 back into the past, to realize the opportunity it presents to us, we must look forward into the future.

Looking back into the past we find an inspiring story of labor encouraged and rewarded by support. It is a story of small enterprise grown great, of slow growth nurtured by dedicated enthusiasts. It is a story of labor from within the University and of support from without. It is appropriate that at this moment of dedication we pause to recapture some of the inspiration of this story.

This great Library seems to have begun in a chest and a closet. There is no reference to any book collection or room in the first college building which Queens College occupied intermittently on the New Brunswick thoroughfare leading down the north slope to the Raritan during the first troubled twenty years of its existence, I 77 II79I. But there is record that during the college's war exile to the North Branch of the Raritan, books were kept in an "old chest" and a closet, books such as Johnson's Dictionary, South's Grammar, and a "compend" of English grammar, and one suspects that there must have been others in Latin, Greek, and Mathematics.

When in I79 I a new college building was ready for occupation at New Brunswick where the highway leading to the south (now Livingston Avenue), turned off of George Street, there came the first benefaction. In that year, Dominie Peter Leydt (Rutgers, I 782) of Franklin Township, Bergen County, perhaps warned that his short 
life span was nearly run, pondered the problem of the disposition of his worldly possessions, particularly his books and his "large black horse." He was a man whose life had been peculiarly close to Queens College. His father, Reverend John Leydt, had been a power in the founding. As minister of the Dutch Church at New Brunswick, he had labored hard for the charter, he had fought successfully against the brethren at Hackensack to get the new foundation established at New Brunswick and he had been one of the executive committee who had managed the college in its early years. Peter's brother, Matthew, had been the first graduate of Queens, and his sister, Cathalyntie, had married into the Van Bunschoten family, who were to produce later, in most dramatic fashion, the first endowment fund. So it was natural that the Franklin Dominie should bequeath "to the Trustees of Queens College in New Jersey all my Latin, Greek and Hebrew books." To his executor went his "large black horse." The warning was timely for the Dominie's will, signed in June, I 79I, was proved in August. The next year his executor advised the trustees that the books were available and their receipt was soon acknowledged. Presumably, there were more of them than could be accommodated in an old chest and a closet, so somewhere in the new college building there must have been a spot called a library. Dominie Leydt was but the first of the long succession of benefactors.

In the years that followed, despite the fact that the College had twice to suspend its operations, its prep school and theological instruction continued. It achieved a third building, Old Queens, and its library grew. When Queens building was finally completed in I 825, after sixteen years of intermittent construction, the College Library which in I8I4 had been advertised as "considerable," was given a home in that room where the Trustees now meet and where some of us learned to think under Marvin's enlightened instruction. The books were under the care of a student in the Theological Seminary who kept the library open one half-hour each week on Saturday morning from 8:30 to 9:00 o'clock.

But it was evidently a library heavily theological and classical. The youth of the day were interested in something with a more secular and modern touch, so the two literary societies founded at the opening of the new era, when in I 825 Queens became Rutgers, undertook to fill the gap. Philo and Peitho began to collect rival li- 
braries as well as to conduct rival assemblies. During some twenty years of activity, they acquired enough books to find themselves with no adequate place to keep them, so they joined with others in a move which caused the faculty to write a distinguished friend of the College. Mr. Abraham Van Nest of New York City had been long interested in Rutgers and when in 1843 he received this letter from the faculty setting forth the need for a new building "for the accommodation of the Library, the Museum, the Laboratory, the Literary Societies, and for other purposes" he responded generously. In I 847 Van Nest Hall was completed and the two best rooms on the ground floor were assigned to Philo and Peitho where adequate cases were installed for the books; some of us learned our history from Johnny Logan in the room on the right as we entered. However, the College library was not moved. Not until near the close of the century were the books of the literary societies and the main libraries united.

In the meantime, benefactors had continued to give books and money. When Dr. John De Witt died in the I 830 's, friends of the library went out and raised what for those days was a really formidable sum, $\$ 2,000$, for the purchase of his library. Dr. Alexander McClelland of the faculty gave so much attention to the ordering and conducting of the library that he was thanked by the trustees. Another devoted faculty member, Professor Peter I. G. Hodenpyl, compiled a catalogue of the holdings, and then the College was unable to find the money to print it. This was before the days of card catalogues and the fashion was to print a booklet. By I 845 the holdings numbered 5,000 books.

Thirty years later, another benefaction made it possible for the library again to think of more adequate quarters. In the 1870 's money from the estate of Sophia Astley Kirkpatrick became available and the decision was made to build a chapel in her honor. But half of this building, the western portion, was to house the Library, now painfully cramped in its classroom home. Notable gifts of books and endowment also came to aid in building the collections. The widow of the Honorable John Romeyn Brodhead, and such book lovers as P. Vanderbilt Spader, and Benjamin Stephens made their gifts. By I 882 there were I0,000 books and two years later a young man of the Class of I 88I, Irving Strong Upson, became the first working librarian. Hitherto, faculty members had spared some time occasion- 
ally in the midst of heavy teaching duties. By r89 1 the collections numbered 26,000 volumes and the western half of the chapel was getting ever more crowded.

The dawn of the twentieth century brought a truly great benefaction. Two loyal friends of Rutgers, John and Elizabeth Rodman Voorhees gave the building which was to bear their name and was at last to be "The Library," devoted solely to books and students. In I 904 it was ready and Mr. Upson, who was also registrar and treasurer, gave place to his assistant, George A. Osborn, of the Class of '97 who was to give himself wholly and unsparingly to the direction of the library and the expansion of the collections now in the neighborhood of 50,000 volumes. He labored mightily and in the next twenty years the books grew to over I00,000 in number and another Voorhees benefaction added space doubling the building in size.

By the I930's Rutgers had become a University, the student body had expanded, the book collections were increasing, the faculty was becoming more research minded and it was again obvious that there must be some new effort. The Clothier Administration and the Library Committee of the Board of Trustees took up the problem and began to seek for the ways and means to secure a great new building. When Mr. Osborn retired, Professor Donald F. Cameron of the English Department, a lover of books, a student of library trends and a talented maker and executor of plans, was appointed librarian. He was first given two years to make the proper preparations and then in 1945 assumed full charge of bringing the great dream into reality.

Now came a great combination of labor from within the university and support from without. It is my happy privilege on this great day when we are rejoicing in visions realized, in prayers answered, and labors crowned with almost unbelievable success to mention and to pay grateful but wholly inadequate tribute to at least a few of those who have put their strength at the disposal of the University. They have been true followers of Leydt, of Van Nest, of Mrs. Kirkpatrick, of Mr. and Mrs. Voorhees, and their names will likewise be inscribed imperishably upon the tablets of our gratitude.

I would speak, though all too briefly, of the invaluable services of those within the University family who have given support and encouragement to this great project. There have been the members of 
the Faculty Library Committee who have worked with such full knowledge of the problem, such intelligent grasp of the means needed, and such enthusiasm for its solution. There have been the administration leaders, President Robert C. Clothier, Provost Mason W. Gross, and President Lewis Webster Jones, who have combined leadership with that capacity to cooperate with our friends at Trenton so vital to the success of the project.

I wish particularly to express my personal appreciation to my associates on the Board of Trustees, to the members of the Committee on Buildings and Grounds, and particularly to those who have labored with me on the Committee on the Library, Mrs. Edward L. Katzenbach, Judge Clarence E. Case, Judge Philip Forman, Col. Robert Kriendler, and particularly my predecessor as chairman, the late Dr. Ralph G. Wright. It is a matter of great regret to all of us that he could not have lived to see that to which he contributed so much. He was generous in time, effort, and substance, and his great part in this must never be forgotten.

Passing outside of the immediate University family we have found help from among interested book-loving individuals who have associated themselves as Friends of the Library. Likewise, certain of the Alumni have given us their support in encouragement, money, and books. Three of the more recent classes, those of 1929, I933, and 1936, have given the Library valuable books and some very welcome funds.

In unrolling the scroll of our benefactors, we pause long and pay particular attention to those connected with the government of New Jersey. This library is the generous gift from the state in recognition of the great role which it and Rutgers play in the education of Jersey youth. We are indeed grateful to the members of the state legislature, the members of the appropriation committees, the budget officers, the Commissioners of Public Instruction and the State Board of Education. From among these many people over the decade in which this great project was developing, we found many friends, all of whom have made their welcome contribution.

Among all our benefactors since Dominie Leydt, none has gained our gratitude in larger measure than the Honorable Alfred E. Driscoll, recently governor of the State of New Jersey. As ex-officio chairman of the Board of Trustees of Rutgers and as chief executive 
and budget officer of the state, he had the responsibility for studying the needs of Rutgers and making budget recommendations to the legislature. He had the educational leader's comprehension of the key need in the transformation of Rutgers into a great state University. He caught the significance of the library. As he expressed it, the library was the university's great locomotive without which the educational train could not run. He, likewise, had the capacity as leader necessary to secure the needed money from the legislature. But the $\$ 4,000,000$ required had to be secured in two installments, which meant action by two legislatures and the danger that we might be left with but half of the library and a vain hope of the rest "sometime." Twice the legislature acted favorably upon his recommendation and because of his insistence. Finally, he was keen enough architect and engineer to fix upon a sum adequate for the purpose, so that we really had enough, and wonder of wonders, did not have to go back for more. Truly Governor Driscoll has been the library's greatest benefactor and to him Rutgers' gratitude will be forever recorded.

This, then, is the story of the labor and of the support which have made possible this great storehouse which we are now to dedicate. The labor and the support have come from both within and without. I have failed in my purpose if I have not made it plain that Rutgers has achieved this structure only because she was able to communicate her message of mission so effectively that the public and private outside help needed was enlisted in amount generous enough to make it possible.

But we can only pause briefly to rejoice and to give thanks. The work which commands us is never done nor can our need of support ever cease, unless we are to close up. Rutgers by the law of 1956 is entering into a new phase of relationship to New Jersey. It has pledged itself anew to the service of the state, and New Jersey has, in return, pledged her faith to us. Such a magnificent union of purpose augurs an educational advance unprecedented in the history of American Education. What a happy omen that I 956 should witness both the completion of this great new source of intellectual power and the state's new recognition of public responsibility for the higher education of New Jersey's youth.

In the name of the people of New Jersey whose creation this great library truly is, and on behalf of the Governors and Trustees of Rut- 


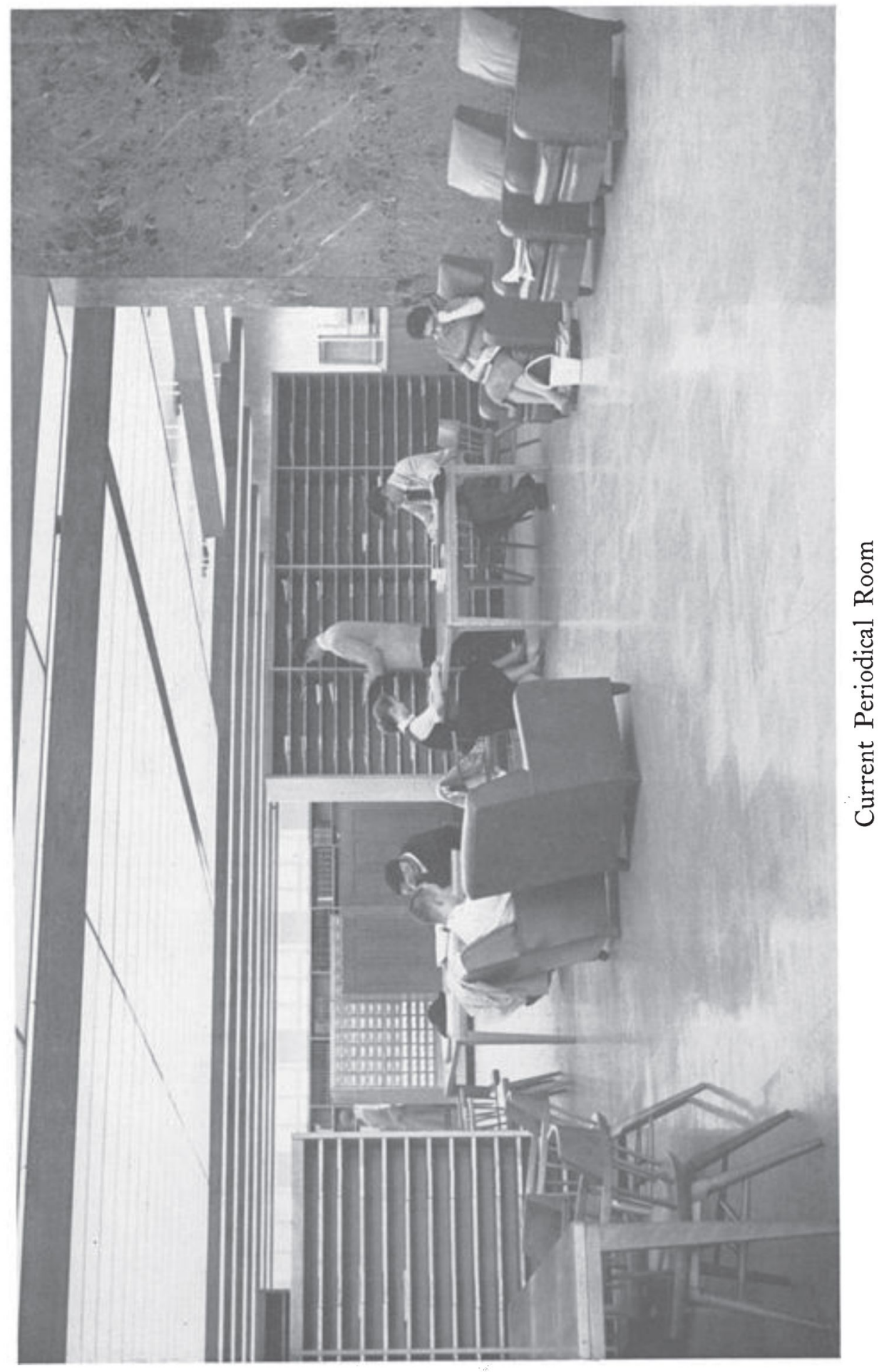




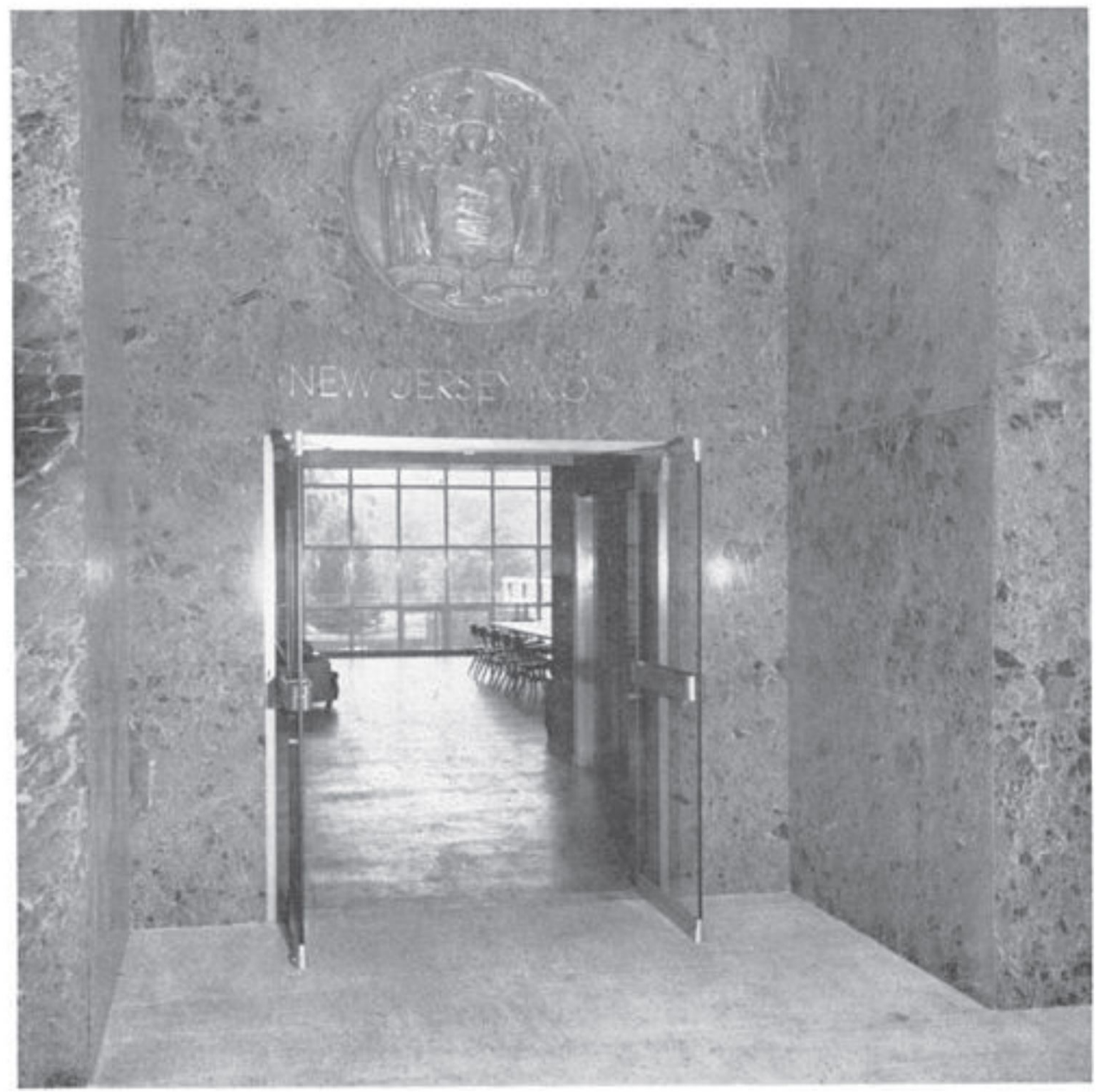

Entrance to The New Jersey Room, which houses the library's rare books and manuscripts

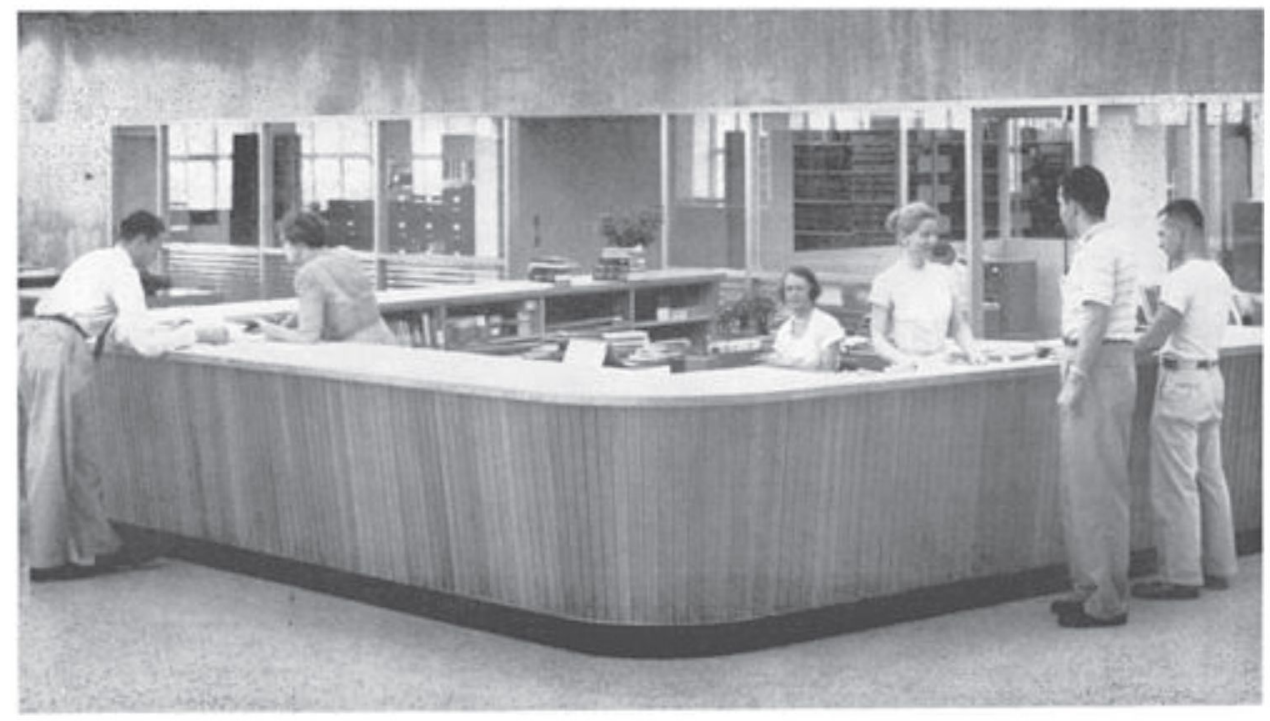

Loan Desk in the new library 
gers who have committed to me this welcome responsibility, I dedicate this building to two great tasks: the higher education of generations of young men and women and the ceaseless extension of human knowledge.

I metaphorically open its doors to all those who through the succeeding decades will here seek to add to the resources of men's minds. And in so doing, I would write over these portals as inscription and command: "Ye shall know the truth and the truth shall make you free."

In this act of dedication, I charge the men and women of Rutgers, governors, trustees, administration, faculty and students, and likewise the citizens of New Jersey, never to falter either in their belief in the truth and its free expression or in their support of this great University which they and their forbears have achieved. More than anything else, the desire for truth and its free dissemination are the surest safeguards of the Democratic idea throughout the world.

Upon the occasion of this dedication I invoke the Sun of Righteousness ever to illumine the paths of those who administer this building and of those who here seek the truth, to make these paths plain and the progress of the seekers sure.

The act of dedication of this great Library, the fruit of the labors of so many over so long a time, is now completed. The doors of this great laboratory and storehouse are open. Rutgers, the State University, invites all to make full use of its treasure, the saving wisdom of mankind. May it be used for the advancement of the cause of truth and for the healing of the nations. 